Binghamton University

The Open Repository @ Binghamton (The ORB)

The Society for Ancient Greek Philosophy Newsletter

$5-1987$

\title{
The Plotinian Reduction of Aristotle's Categories
}

Christos C. Evangeliou

Towson State University, cevangeliou@towson.edu

Follow this and additional works at: https://orb.binghamton.edu/sagp

Part of the Ancient History, Greek and Roman through Late Antiquity Commons, Ancient Philosophy Commons, and the History of Philosophy Commons

\section{Recommended Citation}

Evangeliou, Christos C., "The Plotinian Reduction of Aristotle's Categories" (1987). The Society for Ancient Greek Philosophy Newsletter. 185.

https://orb.binghamton.edu/sagp/185

This Article is brought to you for free and open access by The Open Repository @ Binghamton (The ORB). It has been accepted for inclusion in The Society for Ancient Greek Philosophy Newsletter by an authorized administrator of The Open Repository @ Binghamton (The ORB). For more information, please contact ORB@binghamton.edu. 


\section{THE PLOTINIAN REDUCTION OF ARISTOTLE'S CATEGORIES \\ By \\ Christos C. Evangeliou \\ Towson State University}

I

In Ennead VI. 3., Plotinus proposed a fivefold set of categories which, he thought, can sufficiently account for the sensible world, unlike the tenfold Aristotelian set which he sharply criticized, especially in VI. 1., as ontologically inadequate and logically redundant.1 He found it necessary to criticize the Aristotelians in this way because, inter alia, "In their classification they are not speaking about the intelligible beings." 2 In view of the fundamental (for the pure Platonists) distinction between the intelligible and the sensible worlds, Plotinus' charge means that Aristotle erred in directing his inquiries towards the latter to the neglect of the former which, nevertheless, comprises "the most important beings." 3 Since Aristotle's categories fail to function as "genera of Being," in Plotinus' view, they lose to Plato's megista genē as presented in Sophist 254a-256e and elaborated in Ennead VI. 2.5

Had Plotinus written the treatises of VI. 1. and VI. 2., but not VI. $3 ., 6$ he would have perhaps proven himself a faithful follower of Plato and a capable defender of Platonism. ${ }^{7}$ He would have perhaps shown why the Aristotelian (and the stoic for that matter) set of categories are inapplicable to the intelligible realm of real Being, as the Platonists understood it. But he would have left a gap in his philosophical system by not providing a categorial account for the sensible world, especially because he was not prepared to accept the same set of categories for the realm of real Being and the realm of mere becoming. 8

By proposing a new set of categories for the sensible world, Plotinus decided to go beyond Plato and challenge Aristotle and the Stoics in their field of expertise, this sensible world. ${ }^{9}$ With regard to Aristotle's categories, his central claim is that, even when restricted to this field, it is in need of a drastic reduction and Platonic modification, as we will see presently.10 Thus the proposed Plotinian set numerically corresponds to Plato's five megista genē, though in terminology it clearly resembles Aristotle's set of categories, reduced and modified.

Given the significance of Aristotle's doctrine of categories in shaping our philosophical tradition and its relevance in contemporary methodological debates, 11 the arguments of Plotinus in rejecting or replacing certain Aristotelian categories cannot fail to be of interest to us. For the most part, the Plotinian arguments are philosophically challenging, though occasionally complex and difficult to follow. ${ }^{12}$ There is no doubt, however, that Plotinus was seriously concerned with the problem of determining the number and explaining the nature of the categories of becoming as opposed to the genera of Being.13

In order to be able to follow Plotinus' strategy with some 
understanding, it will be helpful to keep in mind the following facts and important distinctions: (1) That in VI. 3., Plotinus searches for a new set of categories of becoming and not for genera of Being which he had discussed and determined in VI. 2.; (2) that for Plotinus the term genos as opposed to the term katēgoria, as well as the term ousia as opposed to the term genesis, are reserved for the intelligible realm of real Being as opposed to the sensible realm of mere becoming; 14 (3) that the two realms are related to each other as archetype to its image; 15 and (4) that, as a result of this ontological relation, the danger of homonymy is permanently present in any attempt to think and to speak logically about the entities and the activities of each of these two, ontologically distinct, domains. 16

In this context, I propose to consider the Plotinian reduction of Aristotle's categories, especially as presented in the problematic VI. 3. 3. The following questions will be discussed: Which of the Aristotelian categories did Plotinus consider dispensable and for what specific reasons? Are there any non-Aristotelian categories in the Plotinian set and, if so, where do they come from and how do they function? By what method, if any, did Plotinus determine the number of his set of categories and why just five? Finally, why is it that Plotinus is the last, in a long series of Platonists, to sharply criticize Aristotle's doctrine of categories? For it is known that his followers and admirers became increasingly interested in (and commented favorably on) Aristotle's categories. With this in mind, we may now turn to the relevant texts for enlightenment.

\section{II}

According to Porphyry's division and thematic arrangement of the Enneads, the treatise of VI. 3. comprises twenty-eight chapters of which the first three are devoted to preliminary investigations leading to the specification of the definite number of categories of becoming, while the remaining chapters are proportionally allocated to the discussion of each category in accordance with their relative merit. Of the introductory chapters, the most important for our purposes is the third chapter, that is, VI. 3. 3. It is here that Plotinus attempts to answer certain fundamental aporiai, which were raised in the two previous chapters, and to provide us with some clues about the method by which he arrived at his fivefold categorial list. 17

For example, Plotinus states that, having completed the investigation of kosmos noetos in the treatise VI. 2. and having ascertained the need for new "genera" or, rather, categories for kosmos aisthētos, he will turn his attention to the realm of genesis which, unlike the realm of ousia, is something syntheton because it is composed of matter and form.18 But he insists that the search for categories of the sensible realm should leave out of consideration the formal aspect of this realm as an alien element: "Just as if someone wishing to classify the citizens of a city, by their property assessments or skills for instance, 
left the resident foreigners out of account" (VI. 3. 1.26-28).

Next, Plotinus explains that he will use the term ousia to refer to the sensible "so-called substance."19 For Plotinus any sensible substance is only homonymously called ousia and it would be preferable, he suggests, if we could follow the author of the Timaeus (27Dff) and call it instead genesis (VI. 3. 2. 1-5). Since this sensible so-called substance can be divided into bodies and their incidentals or consequences, 20 Plotinus sees two distinct approaches to the problem of devising an adequate categorial scheme, the analytical and the analogical approach.

According to Plotinus, philosophical analysis shows that sensible objects are composed of matter (hylë) and form (eidos). However, he immediately proceeds to raise the following questions in a clearly Aristotelian manner:

But what is the common factor of matter and form? For what essential differentiation is there belonging to matter? But in what genus is the product of both to be ranked? If the product of both is itself bodily substance, and each of them is not a body, how could they be ranked in one and the same genus with the composite? (VI. 3. 2, 10-14)

As for the analogical approach, Plotinus considers it briefly but he rejects it on the ground that the differences between the intelligible and the sensible realms are much greater than any similarities to warrant reliable results. For instance, it is possible to consider the matter and form of sensible objects as playing here below the roles which ousia and kinēsis respectively and authentically play in the intelligible world: But this analogy would not work to plotinus' satisfaction:

Now, first of all, matter does not hold or grasp form as its life and activity, but form comes upon it from elsewhere and is not one of matter's possessions. Then, in the intelligible the form is activity and motion, but here below motion is something else and an incident: but form is rather matter's rest and a kind of quietness for it limits matter which is unlimited. (VI. 3, 2, 22-27) 21

Having thus found both approaches, the analytical and the analogical, unsatisfactory, Plotinus tries a new approach in VI. 3. 3, as follows:

But let us explain how we should divide: this is the way to begin with; it is one thing to be matter, another to be form, another to be the composite of both, and another to be the peripheral characteristics: 22 and of these peripheral characteristics, some are only predicated, some are also incidental: and of the incidentals some are in those three, [matter, form, and composite], but in other cases these 
three are in the incidentals; others are their activities, others their passive affections, and others consequences. And matter is common and in all the substances, but is certainly not a genus, because it has no essential differences, unless one understood the differences as one part having a fiery shape and one the shape of air. But if one was satisfied with what is common, that there is matter in all existing things, or that it is like a whole in relation to parts, it would be a genus in another sense: and this would be one element, and an element can be a genus. But the form, with the addition "about matter" or "in matter," separates from the other forms, but does not include all substantial form. But if we mean by form that which makes substance, and by rational formative principle that which is substantial according to the form, we have not yet said how substance is to be understood. But as for that composed of both [matter and form] if this alone is substance, matter and form are not substances: but if they are also this, we must investigate what they have in common. ${ }^{3}$ But the characteristics which are only predicated would come under relation, being a cause or being an element for instance. And the incidental characteristics in the three would be quantitative or qualitative, in so far as they are in them; as for the cases where the three are in the incidentals, this would be like place and time; 24 their activities and passive affections would be like movements; their consequences like place and time, the place a consequence of the composites, the time of the movement. But the three will go into one, if we can find something common, the ambiguous substance here below: then the others will follow in order, relation, quantity, quality, in place, in time, movement, place, time. Or, if one leaves out place and time, "in place" and "in time" are superfluous, so that there are five, 25 on the assumption that the first three are one: but if the first three do not go into one, there will be matter, form, composite, relation, quantity, quality, movement. Or these last also could go into relation: for it is more inclusive. (VI. 3. 3, 1-31) 26

Regarding the correct interpretation of this admittedly difficult passage, two general observations would seem to be in order before we come to consider specific points of interest. First, it is evident that Plotinus had to take the sensible socalled substance as the starting point for his theorizing about the categories of becoming, in spite of all the reservations which he had expressed in the previous chapters. Second, his analysis of the sensible so-called substance is twofold: (1) In terms of matter, form, and the composite; (2) in terms of its "peripheral characteristics," as Armstrong periphrastically renders the cryptic expression of the text, peri tauta. ${ }^{2}$

It should be noted here that the peri tauta are first identified by Plotinus in general (and not always Aristotelian) 
terms such as katëgoroumena (predicables), symbebëkota (accidents or accidentals), energēmata (activities), parakolouthēmata (consequences), pathe (passions or affections); then, they are assigned more specific names which are taken from Aristotle's categorial nomenclature, as the attached Tables $A$ and $B$ indicate.

\section{I I}

A comparative examination of the tentative Plotinian lists of categories, especially the fivefold list which was finally adopted, with the traditional Aristotelian tenfold list yields some very interesting results. To begin with, perhaps the most striking difference between the two lists is their respective lengths. The Aristotelian list has twice as many members as the Plotinian list. Clearly Plotinus thought of half of Aristotle's categories as unnecessary, redundant and reducible. What his reasons for such a drastic reduction were is a question which must be carefully considered but it cannot be answered satisfactorily before we have (1) identified those Aristotelian categories which were left out of the Plotinian list and (2) have seen how they functioned within the Aristotelian categorial scheme. We will consider these points presently, but first something should be said about plotinus' preference for five as the correct number of categories for the realm of becoming.

In this connection, it may be well to recall that at the beginning of the treatise, which is characteristically entitled On the Genera of Being, Plotinus had briefly discussed the various rival theories of his predecessors regarding the number of the kinds of onta, that is, one being or many beings either infinite or finite in number.28 Without much argument Plotinus rejected both extreme positions, the Parmenidean absolute unity of being and the Democritian infinite multiplicity of beings. 29 Showing awareness of later developments in Hellenic philosophy regarding the correct solution to this problem, Plotinus asserted that the Stoics, the Peripatetics, and the Platonists all agreed on a finite number of "well defined genera." so But they disagreed on the specific number of these "genera" or categories, since they had proposed four, ten, and five, respectively.31 In this light, Plotinus appears as if he sought to uphold a Platonic tradition by opting for a fivefold scheme of categories of becoming in correspondence to the five genera of Being.32 However, as we will see in the next section, he had other and more philosophical reasons for drastically reducing the number of Aristotle's categories. 33

A second characteristic of Plotinus' categorial analysis is that he devotes much space to the discussion of matter and form as prospective categories of becoming distinct from the composite. In three of his tentative lists, matter and form are listed separately as if they were different from the category of the so-called substance. The reason for this uncertainty about the components of sensible substance is that the term ousia had been used by Aristotle to apply to the composite as well as to 
matter and form. Yet it is not clear to Plotinus what all these entities have in common to render such application ontologically legitimate. ${ }^{34}$ He asks poignantly:

What is it, then, which is the same in the three, and what will it be which makes them substance, the substance in things here below? Is it a kind of base for everything else? But matter is thought to be a base and "seat" for form, so that form will not be included in substance. And the composite is a base and seat for other things, so that the form with the matter will be a base for the composites, or at least for all that come after the composites, quantity, quality, movement for instance. (VI. 3.4. 1-7)

Plotinus' questioning pinpoints the dilemma which any analysis of the sensible substance along Aristotelian lines must face. For if matter and form, as components of sensible substance, were themselves substances, it would appear that the composite itself becomes a collection of substances. So it would not be one substance but many. On the other hand, if matter and form were not themselves substances, it would follow that sensible substances derive their substantiality from that which lacked it. In either case one is led to logical absurdities.35 In an effort to overcome such difficulties, Plotinus toyed with the idea of positing form and matter as distinct categories. 36

A third characteristic of the Plotinian categorial scheme is that it comprises other Aristotelian categories, besides ousia. These are the three cardinal categories of poson (quantity), poion (quality), and pros ti (relation, relatives).37 To be sure the names are the same but the functions of these categories are not always Aristotelian. For one thing, they seem to have been strongly colored by stoic influence, especially in the case of quality.38 Then, as a matter of fact, Plotinus does have numerous objections to Aristotle's divisions and stipulative characteristics of each of these categories.39 Furthermore, Plotinus tends to cross over the boundaries of each category as defined by Aristotle in the Categories.

For instance, Plotinus treats quantity and quality as the only symbebekota which are said to be "in" the sensible socalled substance 40 which, consequently, he defines as symphorësis hylēs and poiotētōn, that is, "a coming together of matter and qualities."41 It is clear that in this definition the category of poion has absorbed that of poson. Besides, quality seems to have taken the place of the sensible form or eidos itself so that the composite is considered not as a tode ti (a this) in the Aristotelian nomenclature, but as a poion $t i$ (a qualified something).42 In other words, he seems to question seriously the substantiality of Aristotle's primary substances. Consider:

And the rational form [logos] of man is the being of 'something' but its product in the nature of body, being an image of the form, is rather a sort of 'something like.'s 
It is as if, the visible Socrates being a man, his painted picture, being colours and painter's stuff, was called Socrates: in the same way, therefore, since there is a rational form according to which socrates is, the perceptible socrates should not rightly be said to be Socrates, but colours and shapes which are representations of those in the form: and this rational form in relation to the truest form of man is affected in the same way. And so much for that. (VI. 3. 15, 29-38)

The modern reader would prefer that Plotinus had said much more in clarifying the point which he tries to make in this difficult passage. Apparently he wants to distinguish between the logos of man and the logos of an individual human being, e.g. Socrates. But what the meaning of logos is, in the latter case, is not clear. If logos be interpreted as having the same meaning in both cases, it would seem to follow that plotinus thought of individual substances as being definable, which is contrary to Aristotle's position.44 Such an interpretation may lead to the further suggestion that Plotinus postulated. "Forms" of individuals, as has been argued by some scholars.45

It is possible, however, that logos in the case of Socrates does not stand for definition but for description.46 In this case, the logos of man will give the ti esti (the-what-is-it) of the definiendum, while the logos of Socrates will qualify the ti by the addition of a collection of poiotētes in such a way that the whole product will become a poion ti. If this is a correct interpretation, then the meaning of the above-quoted passage can be captured by an analogy and rendered thus: As the picture of Socrates stands to living Socrates so the logos (description) of Socrates stands to logos (definition) of man. The implication is that for Plotinus, unlike Aristotle, ontological priority must be given to the generic as opposed to the particular. On this, then, Plotinus is certainly closer to Plato than Aristotle was, at least when he wrote the Categories. ${ }^{47}$

Be this as it may, the important point for our purposes is that the categories of quantity and quality, which are prominent in Aristotle's list, have been reduced to relation in at least one of Plotinus' tentative lists. So is every other category except for ousia. Although Plotinus did not in the end adopt this twofold division, it is significant that he even suggested it because it serves as an indication of his tendency to raise the category of relation to its old Platonic status. 48 Given its expansion and elevation to the second place, after ousia, in all the tentative lists of Plotinus, it comes as a surprise that this category is not discussed at any length in VI. 3.49 There is no need for us here to follow the details of Plotinus' different treatment of the Aristotelian category of pros $t i$, since our purpose is to consider which of Aristotle's categories Plotinus deemed reducible and for what reasons.50 To this question our attention should be turned next. 
From Table B it is evident that six Aristotelian categories are missing from the fivefold list which Plotinus adopted. They are: pou, pote, poiein, paschein, echein, and keisthai. 51 Their omission is justified on the grounds that they are unnecessary either because they are reducible to other more fundamental categories or because they are replacible by other newly issued categories. It should be noted here, that even Aristotle had treated these categories only summarily in the Categories where lengthy discussions were devoted to the cardinal categories of ousia, poson, poion, and pros ti. In the very short chapter nine of the Categories, Aristotle (1) asserts that the categories of poiein and paschein admit of contraries and degrees; (2) states that the category of keisthai relates to that of pros ti by means of paronymy only; and (3) concludes his discussion by saying that the meanings of the remaining categories of pote, pou, and echein are so apparent that "I need say no more than I said at the very beginning." Then he repeats the examples which he had used earlier to illustrate the meaning of each of these categories.52

Leaving aside the question of why Aristotle treated these categories in such a summary way, we will concentrate on the reasons for which Plotinus excluded them from his proposed set. If we take them by pairs and start with the weakest of them all, then we will consider first the pair of keisthai and echein. It is the case that these two categories are absent from all enumerations of categories to be found dispersed throughout the Aristotelian corpus with the notable exceptions of Categories $1 \mathrm{~b}$ 25-28 and Topics 103b 20-24.

Our first observation is that plotinus does not refer to this fact in his criticism of these two categories. Nor does he pay any attention to the fact that Aristotle did not elaborate on these categories even when he mentioned them and even where such a discussion would be appropriate, in the Categories. Treating them as legitimate Aristotelian categories, he argues rigorously against their categorial status (VI. 1. 23, 1-24).

Evidently having in mind the polysemy of echein as discussed by Aristotle in Categories 15b 18-25, Plotinus first asks to paraphrase him: Why is it that having shoes or arms on should make up a separate category, while having color, magnitude, a wife, a son, etc. does not? Then, anticipating the probable Peripatetic response that "the mode of having" is different in each of these cases, Plotinus is prepared to make a concession only in order to strike back by asking (not without irony): If "the mode of having," in having shoes on, is sufficient reason for accepting a separate category, what about taking them off or burning them? Should we postulate another category to account for cases like these?

Furthermore, restricting his consideration to the expression of "having on," plotinus is able to argue along these lines: If it is the "on" which makes necessary the postulation of another category to account for such facts as "having shoes on," then 
certainly more categories will be needed to cover cases like "having a table-cloth on" or "having a bed-spread over," since the mode of having differs depending on whether we talk about men, tables or beds. On the other hand, if the emphasis is not on the "on" but on "having," then why not, Plotinus wonders, place these cases of having where Aristotle had placed all hexeis? 53

Finally, and more importantly for Plotinus' critique, in considering the category of echein and, as we will see, the category of keisthai, Aristotle gives the impression that he has forgotten what he had stated at the beginning of his treatise, that is, that the categories were supposed to be about hapla (simple) and aneu symplokēs legomena (uncombined expressions) such as "man," "horse," "runs," "wins" and the like.54 But how is it possible, Plotinus argues, to consider as a simple entity, falling under the heading of one category, something as complex as "that-man-over-there-has-shoes-on?" In instances like this, Plotinus correctly sees two separate beings, a man and his shoes, related in a certain way. But, since the cardinal categories of ousia and pros ti had already been established by Aristotle, the introduction of echein as a new and separate category was a puzzle to Plotinus as it has been to many modern philosophers.55 It might have puzzled Aristotle too, which would explain why he gradually dropped from his categorial set echein and keisthai.

Regarding the category of keisthai, Plotinus has numerous objections which are similar to those which he advanced against echein (VI. 1.24. 1-12). First, he observes that the examples "sitting," "reclining" and the like, are not cases of keisthai simpliciter but of being positioned "in a certain way" (pos). For they indicate respectively that "something occupies a certain place in a certain way" and that "something is situated in such and such a way" (keitai en toiōde schēmati). Now, since for Aristotle (1) schēmata (figures) are considered as one kind of quality (Categories 9b 11-24); (2) topos (place) is considered as one kind of quantity (Categories 4b 20-33); and (3) the categories of quantity and quality have been well-established, Plotinus sees no real need for the category of keisthai which could be reduced to them.

Secondly, Plotinus argues that, if expressions like "is seated" or "sits" (kathetai) indicate activity or passivity, 56 in either case they can be accounted for by the categories of poiein and paschein, both of which are related and, in his view, ultimately reducible to kinessis, as we will see. If so, there is no need for the Aristotelian category of keisthai, since ousia, pros ti, poiein and paschein can very well perform the task which this strange category was supposed to fulfill. The same holds true for the next pair of categories, pote and pou which, in Plotinus' view, can be reduced to chronos and topos respectively both of which Aristotle had classified as continuous quantities. With regard to pote ( $t$ ime in which, when), under which fall such expressions as "yesterday," "last year," "tomorrow" and the like, Plotinus makes the following observations. If these 
expressions denote "parts of time," then they obviously belong to the same category as time and, therefore, they should be placed under quantity where Aristotle himself had placed chronos (Categories 4b 23-26).57 In the case that these expressions do not indicate just time but "time-when," Plotinus is prepared to argue that, in so far as "time-when" relates to time, we must account for it categorially in terms of time. However, in so far as "time-when" is considered as being a combination of two distinct entities, that is, time and that which is an activity in time or a durational event, then clearly we have not one but two categories which means that Aristotle's criterion of categorial simplicity is violated. Even if pote is construed as meaning "being-in-time," Aristotle would seem to run into all sorts of difficulties involved or implied by the multivocity of this "in":

Why will not what is in a pot make another category, and why is not what is in matter something else, and what is in a substance something else, and the part in the whole, and the whole in the parts, and the genus in the species, and the species in the genus? And we shall have more categories.

(VI. 1. 14, 20-24)

The last criticism evidently applies equally to the category of pou (place-in-which, somewhere). Since Plotinus' questioning of pou parallels that of pote, we can afford to be brief here. His arguments are to the effect that expressions such as "in the Lyceum," "in Athens," "above," "below," and the like seem (1) to involve more than one category; (2) to be reducible to topos and ultimately to the Aristotelian category of quantity; and (3) to indicate a certain relation (schesis) "of this in that," and so they can be accounted for by the Plotinian category of pros ti. In any case, there is no real need for a new category of pou.

Turning next to the last pair of questionable Aristotelian categories, poiein (action, acting) and paschein (being acted upon, passion), we may note that they are treated somewhat differently than the other two pairs. In Plotinus'view these two categories are related to kinēsis (motion, movement).58 The fact that Plotinus devoted many chapters to the discussion of this category is indicative of the importance of kinesis as a category of becoming in his set.59 The same fact makes it difficult for us to provide a detailed exposition here of 'Plotinus' many arguments in support of this non-Aristotelian category which he thought was needed. It will suffice to point out only some of the arguments which plotinus adduced to justify the replacement of the Aristotelian categories of poiein and paschein by the Platonic genus of kinēsis. To better understand the disagreement of Plotinus and Aristotle on this important point it will be necessary to briefly recall how the stagirite conceived of kinessis and why he excluded it from his categories.

The third Book of Physics is perhaps the best place in the Aristotelian corpus to look for enlightenment on this matter. There physis is defined as "the principle of movement and change" 
(200b 12-13). One kind of pros ti is identified as "that which is active and that which is acted on, and generally . . . that which moves (or changes) something as the agent and that which is moved (or changed) by it as the patient" (200b 30--34). It is also asserted that "motion and change cannot exist in themselves apart from what moves and changes" (200b 32). Furthermore, "the indefinite and elusive character of motion" is recognized and explained by reference to the fact that kinēsis is located between dynamis (potentiality, potency) and energeia (activity, actuality) (201b 25-28). Subsequently, kinesis is defined as "the actualization of the movable qua movable" (202a 8-9).60 With all this Plotinus has no quarrel. Although he uses a variety of related terms such as odos, agogé, and proodos, all of which carry the meaning of process and passage from one state to another, his conception of kinēsis is basically the same as that which Aristotle's definition reveals (VI . 3. 22, 1-44).

Regarding the kinds of kinesis, Aristotle does not always give the same account. For instance, in Physics 201a 8-9 he states that there are as many kinds of kinesis as there are of being by which he presumably means the ten categories. In the Categories the enumeration of the kinds of kinēsis includes only the following: (1) generation and destruction, (2) increase and decrease, (3) alteration and (4) locomotion (15a 13-14). These correspond respectively to the four categories of ousia, poson, poion, and pou. But in Physics 225a 37-38, Aristotle claims that, strictly speaking, genesis and phthora are not kinds of kinēsis which are thus restricted to quantitative, qualitative and local motions. Plotinus seems to be in favor of the sixfold division as presented in the Categories. To this list he added poiein and paschein as distinct kinds of kinésis which is, thus, elevated by him to the status of a category of becoming.

On this last point the two philosophers certainly disagree. Aristotle never refers to kinēsis as a category. For him it is an intercategorial concept. Like to on (being) and to hen (one), kinësis cuts across many (if not all) categories. It operates between contraries (ta enantia), presupposes a substratum (hypokeimenon, or hylë), and tends towards an end (telos).61

Aristotle also maintains that poiein and paschein are distinct categories, since "acting" and "being acted upon" are different in definition (tö logó), even when one and the same activity is involved as in the case of cutting. The road from Athens to Thebes may be one and the same but the going to and the coming from Thebes is different. For "In these cases we are dealing with one and same thing which may be regarded or defined from two different approaches. So too with the mover and the moved" (202a 20-22). Contrary to this, Plotinus claims that kinēsis deserves to be treated as a category, and more so than such Aristotelian categories as poiein and paschein which can be considered as its kinds. This point needs elaboration so that the difference between the two philosophers will become clear.

According to Plotinus, any candidate for a categorial position should meet three specified criteria: irreducibility to 
any other well-established category, predicability of the highest degree, and capability of yielding species and subspecies by application of the appropriate differentiae. Since kinẽsis passes this test, Plotinus thinks that it should be accepted as a categorial companion to so-called substance together with quality, quantity, and relation (VI. 3. 21. 1-15). But, if kinësis is accepted as a categorial genus, then both poiein and paschein, will have to be considered as its species and, therefore, they will lose their status as separate categories. The possibility of viewing kinēsis as a kind of pros ti and, thus, reducible to relation on the ground that any motion is motion of the movable (tinos kinēsis), cannot be seriously considered, according to Plotinus, because by the same token everything else would be reduced to relation. This would make the categorial set twofold, substance and relation, but such a wholesale reduction would, inter alia, run contrary to the Aristotelian definition of pros ti which Plotinus had accepted with certain reservations. 62

However, the possibility of considering metabole (change) and energeia (act, actuality) as rivals to kinessis for the categorial title is more serious. We may recall here that Aristotle had characterized kinēsis as atelēs energeia (uncompleted actuality) and had considered genesis not as kinēsis but as a metabole $(201 \mathrm{~b} 31-32)$. Could they not, then, be placed higher than kinésis and render null its claim to the categorial status? Plotinus is well aware of this serious challenge and prepared to meet it head on. In a long and involved passage (VI. 3. 21. 25-47), he argues to the effect that either metabole is synonymous to kinësis or, if their meanings differ, "change would be rather a species of movement being a movement which takes a thing out of itself" $(46-47) .6^{3}$

In Plotinus' view, Aristotle's characterization of kinésis as atelēs energeia clearly indicates that energeia is the generic concept and atelēs the specific difference which determines the nature of kinésis. But what the epithet atelēs mean in this connection, is not clear to plotinus. In what sense, he asks, is kinēsis "uncompleted" or "incomplete"? Consider, for instance, walking which is a kind of locomotion. In the walking process every step qua motion is as actual as any other, first, middle or last. To talk of incomplete motion can only mean that we tend to associate walking with the distance to be traversed. Thus, in terms of actuality both energeia and kinésis stand on the same level, Plotinus suggests, and the same holds for their relation to time. For he rejects the claim that kinesis is in time (en chronō), while energeia is not (achronos). In a sense, he insists, neither is "in time" (VI. 1. 16.14-17).

In the light of the above considerations, it seems clear that Plotinus' arguments are intended to establish the following theses: (1) that poiein and paschein can be considered as two distinct kinds of kinësis; (2) that a kinésis can be either absolute (apolytos) or directed towards something else, e.g. walking or singing as opposed to cutting or burning; (3) that in 
the latter case there is one and the same motion, though to cut and to be cut, for instance, are not the same as indicated by the algos (pain) felt; and (4) that as a result of this difference there is a tendency to consider other-directed motions as contrary, that is, as active and passive.

Now that this is not the case can be shown by considering such activities as (a) writing, for it would be absurd to say that the paper is suffering the impact of the pen; (b) hitting, for it is possible that the agent may suffer as much as the other fellow if it happen to be the delicate hand of a lady which struck the blow; and (c) learning through instruction, for the student (the patient) must be as active as the teacher (the agent) if the process is to succeed. However, in clear-cut cases involving action and passion such as healing or burning, Plotinus thinks that "it is the same motion, but looked at on one side it will be action, but on the other passive affection" (VI. 1. 22, 11-13). If so, poiein and paschein can be subsumed under the new category of kinēsis which came to rival ousia in terms of categorial import in the Plotinian scheme. 64

To recapitulate, it is evident that plotinus undertook the task of providing a new set of categories for the sensible realm by drastically reducing the Aristotelian tenfold set and by modifying it in such a way that it became more platonic. The need for such reconstruction was perhaps provided by the fact that Aristotle had not treated all of his categories with equal care, while Plato had emphasized the importance of kinesis as a generic concept necessary for any reasoned account of the sensible and the intelligible realms of being.

Plotinus was able to reduce Aristotle's categories by half by arguing that of the omitted six categories (a) pou and pote are unnecessary as reducible to the category of quantity or even to the category of relation; (b) echein and keisthai do not qualify to be considered as categories because they fail to meet the criterion of generic simplicity, since they involve items which fall under different categories, that is, substance and relation; and (c) poiein and paschein, considered as the two sides of one and the same coin, can be subsumed under the Platonic genus of kinésis with any loss.

Plotinus was the last Platonist to criticize Aristotle's doctrine of categories before it became a part of the Neoplatonic synthesis.65 His project of reconstructing the Aristotelian categorial scheme by reduction and replacement was daring but unsuccessful in that it was not accepted even by his close associates and admirers. For Porphyry, Iamblichus, and Dexippus, did not follow plotinus' lead on this matter. They initiated a new policy of non-confrontation and possible reconciliation of Plato and Aristotle. As a result of this policy the categories were accepted and defended in toto, that is, without any Platonic modification or Plotinian reduction. 66 


\section{FOOTNOTES}

1. In "The Ontological Basis of Plotinus' Criticism of Aristotle's Categories," in The Structure of Being: A Neoplatonic Approach, R.B. Harris, ed., (Albany, New York: SUNY Press, 1982), pp. 73-83, I have provided an account of what I consider to be the basic reasons for which Plotinus could not accept Aristotle's categories.

2. Enneads VI. 1.2. 29-30. The translation is that of Professor Armstrong who was kind enough to let me use his completed but unpublished typescript of the sixth Ennead. Unless stated otherwise, I will follow his translation throughout.

3 . This is my rendering of the expression "ta malista onta" which Armstrong translates as "those which are most authentically beings." For Plotinus' detailed criticism of the Aristotelian and the Stoic sets of categories, see VI. 1., chapters 2-24 and 25-30 respectively.

4. The common title of the three treatises, VI.1., VI. 2., and VI. 3., is Peri tön genōn tou ontos which clearly indicates Plotinus' ontological approach to the categorial problem.

5. Plotinus also refers to Plato's genera in II. 4.5., III. 7. 3., and V. 1. 4. For a concise account of his interpretation of this doctrine, see $E$. Bréhier's introduction to Ennead VI. 2. (Paris: Les Belles Lettres, 1924-1938), pp. 34ff.

6. The division of this treatise and some others (e.g. III. 2. and III. 3., IV. 2., IV. 3, and IV. 5., and VI. 4. and VI. 5.) was the result of Porphyry's editorial effort to reach the

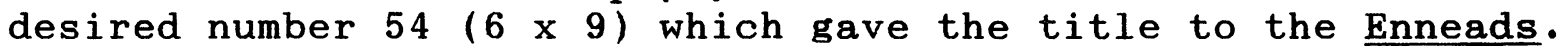

7. As another example of Plotinus' rigorous defense of Platonism, see II. 9., and my "Plotinus' Anti-gnostic Polemic" in Neoplatonism and Gnosticism, J. Bregman, ed., (forthcoming).

8. "For it is absurd to put being under one genus with nonbeing, as if one were to put Socrates and his portrait under one genus" (VI. 2. 1. 23-24). For a recent appraisal of the function of image in Plotinus' philosophy, see J.H. Fielder, "Chorismos and Emanation in the Philosophy of Plotinus," in The Significance of Neoplatonism, R.B. Harris, ed., (Albany, N.Y.:. SUNY Press, 1976), pp. 101-121.

9. This certainly sets Plotinus apart from such Middle Platonists as Albinus, Plutarch, and the anonymous commentator who had found the alleged Platonic categories in Timaeus 35Bff, in Parmenides $137 \mathrm{Cff}$, and in Theaetetus 152Dff respectively. On this see J. Dillon, The Middle Platonists (Ithaca, N.Y.: Cornell University Press, 1977), especially pp. 226 and $279 \mathrm{ff}$.

10. The most important modification, in my view, is the replacement of the Aristotelian categories of poiein and paschein by the category of kinēsis which should be considered as Platonic, since it corresponds to one of Plato's megista gené.

11. For the relevant bibliography, I refer to W.K.C. Guthrie, A History of Greek Philosophy, vol. VI, (Cambridge: Cambridge University Press, 1983); and J. Barnes et al., eds., Articles in Aristotle, vol. 1, (New York: St. Martin's Press, 
1975). For recent discussions, see C. Kahn, "Questions and Categories," in Questions, H. Hiz, ed., (Holland, Boston: D. Reidel, 1979), pp. 227-278; A. Edel, Aristotle (Chapel Hill: University of North Carolina Press, 1982), pp. 97-101; J . Moravcsik, "Aristotle's Theory of Categories," in Aristotle: A Collection of Critical Essays (Garden City, N.Y.: Doubleday and Co., 1967), pp. 125-145; J. Catan, ed., Aristotle: The Collected Papers of Joseph Owens (Albany, N.Y.: SUNY Press, 1981), especially Chapters One and Two; and my paper "Alternative Ancient Interpretations of Aristotle's Theory of Categories," in Language and Reality in Ancient Greek Philosophy, K. Boudouris, ed., (Athens, Greece: Achtida, 1985), pp. 163-173.

12. One of the most serious students of Plotinus, W.R. Igne, has stated that the treatise under consideration is one of "the most obscure and least interesting." The Philosophy of Plotinus (New York: Longmans, 1948), p. 194. Although this statement is partially correct, it may account for the paucity of works devoted to this part of the Enneads. In English there are J.P. Anton's "Plotinus' Approach to Categorical Theory," in The Significance of Neoplatonism (Albany, N.Y.: SUNY Press, 1976), pp. 83-99; and J.M. Rist's Plotinus: The Road to Reality (Cambridge: Cambridge University Press, 1967), especially pp. 103-112. Rist concludes that "Plotinus's view [of the sensible object] is basically the original Platonic position" (p. 111); whereas Anton insists that "with Plotinus we have the appearance of a radically different ontology of the sensible object. If anything, it is non-Hellenic in character" (p. 97). As for the Europeans, two important and recently published books should be mentioned: K. Wurm, Substanz und Qualität (Berlin: Greyter, 1973 ); and C. Rutten, Les catégories du monde sensible dans les Enneádes de Plotin (Paris: Universitaire de Liege, 1961). Neither of these scholars discuss in any detail the passage under consideration. Wurm's main thesis is the contrast between "Der platonische kategoriale Gegensatz von ousia und poion und die nicht-platonische Form seiner Vermittlung in Plotin" (p. 257); whereas Rutten attempts to show that in Plotinus "la connaissance n'a point d'object" by arguing as follows: "C'est donc a défaut de pouvoir identifier la substance à la fonction de genre remplie par son concept que Plotin réduit l'ousia à sa fonction de subjet logique. Un idealisme contrarié se change ainsi en nominalisme" (p. 70 , repeated on pages $82,92,103,112-115$, etc.).

13. About one-tenth of the Enneads is devoted to this topic. Regarding the correctness of Plotinus' interpretation of Plato's genera and the Platonism of Plotinus in general, Anton, op. cit., has expressed reservations, contrary to J.N. Findlay, "The Platonism of Plotinus," in the same volume, pp. 23-41. One of the oddities of interpreting Plato's megista genè as "genera of Being" is that "being" (to on) becomes a "genus of Being!" Hence Plotinus' tendency to substitute ousia for to on in the Platonic list.

14. For a detailed discussion of the term "genus" and "category," see Rutten, op. cit., pp. 42-55. It is significant 
that Plotinus ends his criticism of each Aristotelian category with the invariable comment that they cannot function as genera, let alone the "genera of Being." On this, see note No. 1 above.

15. In reference to the sensible realm, Plotinus throughout the Enneads employs terms like eikōn, eidolon, skia, homoióma, all of which connote the notion of image and indicate the dependence of the sensible on the intelligible kosmos. To use Plotinus' metaphor, it is as if the sensible "hangs upon" the intelligible (anêrtetai, VI. 5, 9. 36 and elsewhere).

16. For instance, in VI. 1.2. 1-3, Plotinus states: "And first of all we should consider what is called substance, agreeing that the nature of the sphere of bodies can only be called substance ambiguously [homónymōs], or should not properly be called substance at all but coming into being, because it is adapted to the idea of things in flux."

17. That this passage is problematic has escaped the attention of both Rutten and Wurm, op. cit. However, Bréhier, op. cit., p. 46, wondered whether we have here "un texte de Plotin ou à quelque maladroite interpolation." I agree with Bréhier that this chapter is difficult to interpret, but even he does not seem to take seriously the suggestion that it may be interpolated.

18. E.g. in $410 \mathrm{a} 1,412 \mathrm{a} 16,1023 \mathrm{a} 31,1029 \mathrm{~b} 23,1051 \mathrm{~b} 19$, Aristotle uses the term "to syntheton" to refer to the concrete individual substance. But for the same purpose he uses more often "to synolon" which denotes a stronger union between matter and form. Plotinus' adoption of the former term stresses the point that eidos is an alien to the world of hyle.

19. The Plotinian expression "ousia legomene" is rendered into English variously by different authors: "pseudo-substance" (Anton), "ambiguous substance" (Armstrong), "what passes as substance" (MacKenna). I prefer the rendering "so-called substance" because it captures better the irony of the legomene.

20. Armstrong's "incidentals" and "consequences" translate respectively symbebẻkota and parakolouthēmata of which the former is Aristotelian and the latter either stoic or Epicurean, according to the apparatus criticus of $P$. Henry and $H$. Schwyzer. Taking into account Porphyry' testimony, Vita Plotini 14, it would be more probable for this term to be stoic than Epicurean.

21. For Plotinus' views on hylē and its kinds, see II. 4.

22. The text has peri tauta, literally "those things which are about these entities [matter and form]," that is, the symbebēkota which, according to Topics 102b 5-8, may or may not belong to a given substance.

23. In VI. 3. 8. 1-37, Plotinus critically examines the characteristics of substance, as found in Categories 5 .

24. Armstrong here translates topos and chronos which are in all probability neglegenter pro en topō kai en chronō, as Henry and Schwyzer have suggested.

25. See the attached Tables $A$ and $B$.

26. The last categories which are reducible to relation are: poson, poion, and kinēsis, that is, every category in the 
Plotinian list except for ousia.

27. About this expression, see note No. 22 above.

28. Of the reasons which Plotinus produces in arguing against an infinite number of beings, the strongest seems to be that which echoes Aristotle's Physics 189a 11-16 and claims that the hypothesis renders episteme impossible (VI. 1. 1. 8-9).

29. This means that, ontologically speaking, Plotinus is not a monist. There are many different kinds of onta, though limited in number. The One qua hypostasis is a different case. Like the Platonic Good, the Plotinian One is beyond being. See on this The Cambridge History of Later Greek and Early Medieval Philosophy, A.H. Armstrong, ed., (Cambridge: At the University Press, 1970), especially pp. 236-250.

30. As MacKenna renders the expression "genē horismena."

31. But the dispute is not just about numbers. Plotinus claims that there is a fundamental ontological difference between the Platonic genera and the Aristotelian (and Stoic) categories, as we said at the beginning.

32. To what extent this choice determined Plotinus' strategy in reducing Aristotle's categories from ten to five is difficult to tell, since numerical correspondence to the Platonic genera is not among his reasons for accepting the fivefold set.

33. Six out of ten Aristotelian categories are excluded from the list of plotinus. The accepted categories are: ousia [logomenē], poson, poion, and pros ti.

34. In contrast to Plotinus, Porphyry states categorically that the ousia to which Aristotle's categories apply is the composite (synamphóteron), Commentaria in Aristotelem Graeca, A. Busse, ed., (Berlin: Reimer, 1887), vol. IV, part 1, p. 88.

35. Evidently Plotinus attempts to exploit the ambiguities of Aristotle's position regarding ousia, as stated in Categories 2a 11-14 and Metaphysics 1031b 6-8, 1037a 27-30, 1037b 33-35.

36. But we should not forget that "The whole amalgam itself [the sensible so-called substance] is not True substance; it is merely an imitation of that True Substance which has Being apart from its concomitants" (VI. 3. 8. 32-34).

37. It is more correct to render the technical expression ta pros $t i$ as relatives or correlatives rather than relation. The former emphasizes the onta which are related, while the latter stresses their schesis. This case is parallel to homonyma [i.e. onta or pragmata], with which the Categories opens. On this, see H. Apostle, Aristotle's Categories and Propositions (Grinnell: The Peripatetic Press, 1980), p. 51-52.

38. See Ennead II. 6., On Quality. For a good account of the Stoic categories, I refer to A. Long, Hellenistic Philosophy (London: Duckworth, 1974), pp. 160-163; also J. Rist, Stoic Philosophy (Cambridge: University Press, 1969), pp. 152-172.

39. See, e.g. VI. 1. 2.-24.

40. The point is that quantity and quality are said to be "in" the sensible substance which, in its turn, is "in" place and "in" time. On the question of their individuation, I refer to G.E.L. Owen, "Inherence," Phronesis 10 (1965): 97-105; R.E. 
Allen, "Individual Properties in Aristotle's Categories," Phronesis 14 (1969): 31-39; and J. Moravcsik, "Aristotle on Predication," Philosophical Review (1967): 80-96.

41. For a detailed analysis of Plotinus' conception of sensible substance, see Wurm, op. cit., especially p. $250 \mathrm{ff}$.

42. But for Aristotle the opposite of this is true. For he notes, in reference to species and genera, that by "man" and "animal" not a "this" but "a qualified something is meant" (Categories 3b 15-17, translation mine). See also Sophistical Refutations $178 \mathrm{~b} 38-40$, and contrast it to De Anima 412a 6-10.

43. Armstrong's translation here is awkward but it seems to reflect the original text. An alternative and more liberal formulation would run as follows: "And the logos of man is its essential being, but the bodily existent is rather a qualified something than a something, since it is an image of logos."

44. For Aristotle the individual receives the name and the definition of its species (Categories 2b 21-27).

45. See the debate between J. Rist, "Forms of Individuals in Plotinus," Classical Quarterly, n.s. 13 (1963): 23-31; J. Blumenthal, "Did Plotinus Believe in Ideas of Individuals?" Phronesis, XI No. 1 (1966): 61-81; and A.H. Armstrong,"Form, Individual and Person in Plotinus," Dionysus, 1 (1972): 49-68.

46. The Greek word is hypographe. It is used frequently by Porphyry and other commentators on the Categories with reference to a description of individuals or of the highest genera which cannot be defined by genus and differentia. It is also found in Aristotle, e.g. On Plants $819 \mathrm{~b} 16$, and De Interpretatione 22a 22 .

47. If the general consensus which considers the Categories as an early treatise is correct, then this point acquires some import, in view of Jaeger's position about Aristotle's progressive estrangement from Platonism.

48. In the Sophist $255 \mathrm{c}$, Plotinus had found the important distinction of onta between the kath auto and the pros alla.

49. To the category of pros ti Plotinus devoted four whole chapters in VI. 1., chapters 6-9.

50. In VI. 3 . capters 1-20, Plotinus states the conditions under which the Aristotelian categories of ousia, poson, and poion could be accepted as "genera" of the realm of becoming.

51. Aristotle's categories are variously rendered into Engish by different authors. See Table $b$ for the most common renderings. I have preferred the Greek terms in tranliteration.

52. Categories 2a 1-5, in Cooke's translation, the illustrative examples are respectively "in the the market-place" and "in the Lyceum", "yesterday" and "last year," "is shod" and "is armed."

53. In Categories 8b 27-29, Aristotle classified hexeis as a kind of poion, while he considered them as a case of pros ti in $10 \mathrm{~b} \mathrm{20-46.} \mathrm{A.} \mathrm{Edel,} \mathrm{op.} \mathrm{cit.,} \mathrm{p.} \mathrm{100,} \mathrm{states:} \mathrm{"If} \mathrm{habits} \mathrm{or}$ states (hexeis) are akin to the category of state (echein; the terms are linguistically related), the whole field of virtues and vices in ethics would be brought within its scope." But by the same token two cardinal categories, quality and relation, would 
be reducible to the dubious category of echein. Such a reduction would be more drastic than that of Plotinus.

54. In Categories $1 \mathrm{~b} 25$, the categories are introduced as aneu symplokès legomena.

55. These two categories have been aptly characterized by Kahn, op. cit., as "anthropocentric," since they seem to function only when the subject of discourse is a man, e.g. Socrates.

56. VI. 1. 23. 4-6. This Plotinian either/or is a false dilemma, because in Greek grammar between the active and passive voices there is the middle voice, to which Aristotle's examples refer with regard to the category of keisthai (which, by the way, examplifies this middle voice).

57. On this point, Aristotle would disagree with Plotinus. As an Aristotelian category pote does not stand for measurable time in general, but for determined time during which something occurs. Simplicius, Commentaria in Aristotelem Graeca, vol. VIII, (Berlin: Reimer, 1907), pp. 301ff.

58. Kinèsis is the only Plotinian category which exactly corresponds to the homonymous Platonic genus. For recent debates of this concept, see J. Ackrill, "Aristotle's Distinction Between Energeia and Kinësis," in New Essays on Plato and Aristotle, R. Bambrough, ed., (New York: Humanities Press, 1965), pp. 121-141; R. Polansky, "Energeia in Aristotle's Metaphysics IX." Ancient Philosophy, III, No. 2 (1983): 160-171; P.S. Mano, "Energeia and Kinésis in Metaphysics Theta 6," Apeiron 4 (1970): 24-34; and L.A. Kosman, "Aristotle's Definition of Motion," Phronesis 14 (1969): 58-9.

59. VI. 1. 3. 21-27.

60. The translation of the quotations from the physics is that of P.H. Wicksteed and F.M. Cornford (Cambridge, Mass.: Harvard University Press, 1970).

61. See, e.g. Metaphysics $1046 \mathrm{a}-1048 \mathrm{~b}$, Nicomachean Ethics $1174 a-1175 b$, and De Anima 431a-b.

62. In my translation, Aristotle's definition of pros ti reads as follows: "Relatives are called those things which, in order to be what they are, are said to be of something else or somehow related to something else." In Ackrill's rendering of the same passage we read: "We call relatives all such that are said to be just what they are, of or than other things, or in some way in relation to something else."

63. The term, which Aristotle uses in $222 \mathrm{~b} 16$ with reference to change and which is echoed here, is ekstatike.

64. According to Simplicius, op. cit., p. 306-308, Plotinus has been influenced by the Stoics here. Perhaps Aristotle wanted to keep poiein and paschein as separate categories because some activities do not imply passivity (i.e. noein) or reciprocity (i.e. to kinoun akiniton which he mentions in 201a 24).

65 . For a complete list of commentators and critics of the Categories, see Simplicius, op. cit., pp 1-2.

66. I discuss this problem thoroughly in my forthcoming book, Aristotle's Categories and Porphyry, which has been accepted for publication in the series Philosophia Antiqua. 


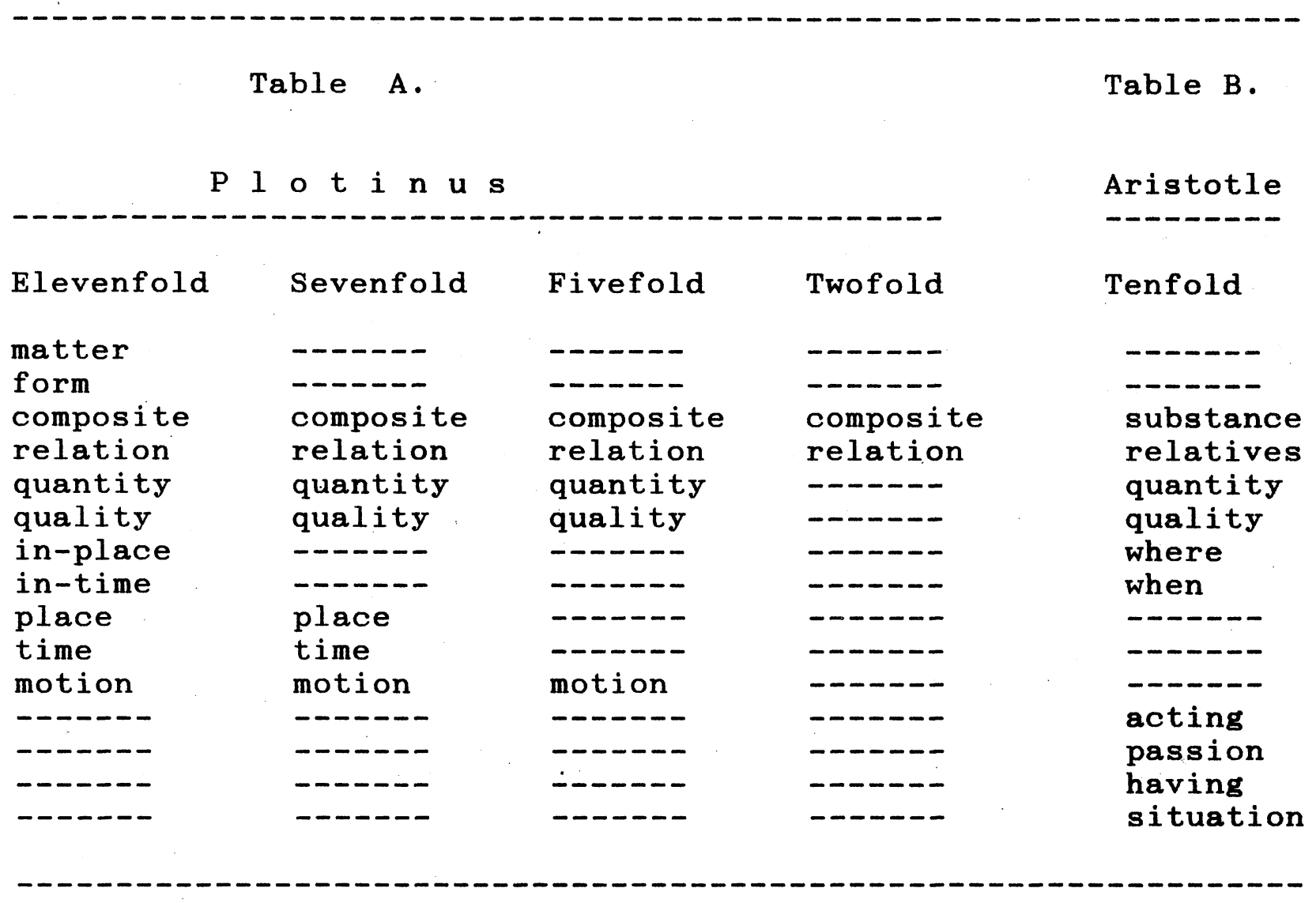

